\title{
POTENTIAL UTILISATION OF UNTREATED/TREATED TEXTILE EFFLUENT IN CONCRETE
}

\author{
M.Kanitha ${ }^{1}$, P.Ramya ${ }^{2}$, V.Revathi ${ }^{3}$, S.Bhuvanya ${ }^{4}$ \\ ${ }^{1}$ PG Student, Civil Engineering, EBET Group of Institutions, Kangeyam, Tamil Nadu, India \\ ${ }^{2}$ Assistant professor, Civil Engineering, EBET Group of Institutions, Kangeyam, Tamil Nadu, India \\ Professor and Head, Civil Engineering, K.S.R College of Engineering, Tiruchengode, Tamil Nadu, India \\ ${ }^{4}$ PG Student, Civil Engineering, EBET Group of Institutions, Kangeyam, Tamil Nadu, India
}

\begin{abstract}
This paper reports the experimental findings to predict the practicability of using treated textile effluents as alternative to fresh water in mixing concrete. Potable water was replaced with four stages of effluents in the textile effluent treatment process (ETP) namely, collection tank water (CTW), Anaerobic outlet water (AOW), Tertiary clarifier water (TCW), Reverse osmosis feed water (ROFW). The chemical compositions of the treated effluents were investigated. Concrete specimens were assessed with hold to setting time, workability, compressive strength and split tensile strength. The specimens made with AOW attained higher strength than the specimens made with potable water. It was noticed that the compressive strength was increased by $26.15 \%$ for AOW in comparison with $P W$ at the age of 28 days. It can be concluded that $A O W$ can be used as an alternate to freshwater for mixing concrete.
\end{abstract}

Keywords: Concrete, textile effluent, collection tank water, anaerobic outlet water, Tertiary clarifier water, Reverse osmosis feed water.

\section{INTRODUCTION}

The world's ever increasing population and its progressive adoption of an industrial based lifestyle has inevitably led to an increased anthropogenic impact on the biosphere. Global water pollution scenario suggests that nearly 1.5 billion people lack safe drinking water and at least 5 million deaths are attributed to waterborne diseases such as cholera, hepatitis every year. The major industries contributing to water pollution are textile mills, electroplating industry, metal processing industry, pulp and paper mill and tannery industry.

The textile industry in India guzzles double the accepted amount for consumption. A major factor is obsolete technology that permits minimum recycling and reuse of process water. For instance most textile mills in India do not use counter-washing systems instead they use clean water at every stage of the wash cycle. Discharges of highly colored dye effluents in natural water constitute one of the most important problems of the surface water. Amaravathi river basin at the downstream of Karur town is severely polluted due to discharge of partially treated effluent by the textile bleaching and dyeing units. There are 487 units and they treat the effluent either in individual effluent treatment plant (IETP) or common effluent treatment plant (CETP). Daily about $14600 \mathrm{~m}^{3}$ of coloured effluent with TDS $5000-10,000 \mathrm{mg} / \mathrm{l}$ is let into river Amaravathi. The groundwater quality modeling of Amaravathi river basin was done and the simulation results say there is no improvement in ground water quality even the effluent meet the discharge standards for the next ten years. When the units go for zero discharge then there will be an improvement in the quality of groundwater over a period of few years [19].

Construction is one of the major water consuming industries. The industry attains rapid growth which leads to abundant utilization of water. At an average of $250 \mathrm{~kg}$ of cement per $1 \mathrm{~m}^{3}$ of concrete and 0.5 water/cement ratio, approximately 800 billion liters of water were used in the production of concrete during the year 1997[2]. The amount was further estimated at 825 billion liters in the year 2010[20].

ASTM C 1602/C 1602M-06 (2006) outlined the requirements of non potable water to be used as mixing water in concrete. The compressive strength of concrete made with non potable water should not be less than $90 \%$ of the compressive strength of control mix and the deviation in the time of set of concrete should be 1.00 hours to 1.30 hours. The treated domestic sewage can be used as mixing water for concrete and the properties such as setting time, strength, drying shrinkage and durability may be affected due to the presence of high amount of impurities in the mixing water [15].The concentrations of inorganic substances such as lead, copper, manganese and zinc beyond $500 \mathrm{ppm}$ should not be used in the mixing water meant for cement works [14]. 
The objective of this research work was to evaluate the feasibility of using treated textile effluents as mixing water for concrete. This study describes the chemical properties of textile effluents in every stage of treatment, setting time, compressive strength and split tensile strength of concrete specimens.

\section{MATERIALS}

\subsection{Cement}

The ordinary Portland cement (OPC) of 53 grade was used for the experimental study. The properties of cement are given in Table 1.

Table-1: Properties of Cement

\begin{tabular}{|l|l|}
\hline Properties & Observed Value \\
\hline Specific gravity & 3.13 \\
\hline Consistency & $31 \%$ \\
\hline Fineness & $2.33 \%$ \\
\hline Initial setting time & $80 \mathrm{mins}$ \\
\hline Final setting time & $105 \mathrm{mins}$ \\
\hline
\end{tabular}

\subsection{Fine Aggregate}

The locally available river sand was taken as the fine aggregate. The properties are conducted as per BIS 2386-1963 and are presented in Table 2.

Table-2: Properties of Fine aggregate

\begin{tabular}{|l|l|}
\hline Properties & Observed Value \\
\hline Specific gravity & 2.72 \\
\hline Fineness modulus & 2.135 \\
\hline Zone & II (BIS 383-1970) \\
\hline
\end{tabular}

\subsection{Coarse Aggregate}

Crushed stone aggregate of $20 \mathrm{~mm}$ was used in this study. The basic properties obtained from the test results are given in Table 3.

Table-3: Properties of Coarse aggregate

\begin{tabular}{|l|l|}
\hline Properties & Observed Value \\
\hline Specific gravity & 2.67 \\
\hline Water absorption & $0.6 \%$ \\
\hline Crushing value & $22.6 \%$ \\
\hline
\end{tabular}

\subsection{Mixing Water}

Effluent samples taken from the dyeing industry in Karur. Karur is one of the places with large textile process where location of dyeing industry remains certain. The dyeing industry consumes totally 3225 liters/day for dyeing process. The samples collected were examined for the impurities which may affect the concrete properties. The chemical parameters of water samples are tabulated in the Table 4. Besides, potable water available in EBET campus was used.

\section{EXPERIMENTAL INVESTIGATION}

\subsection{Cement Pastes}

Cement pastes were made to study the setting time for the various water samples taken. Setting time is essential for proper concreting that the initial setting time be sufficiently long for transporting and placing the concrete. Setting time was followed after the consistency tests with five sample of water including potable water. The test were conducted in the accordance with the IS codes 4031(Part 4)-1988, 4031 (Part5) -1988 .

\subsection{Cement Mortar Cubes}

Cement mortar cubes were prepared to determine the compressive strength of cement with the water samples taken. The procedure given in IS: 4031(part 6)-1988 was adopted to determine the $\mathrm{w} / \mathrm{c}$ ratio of cement mortar. Five different mixes were prepared using the cubes of $70.6 \times 70.6 \times 70.6 \mathrm{~mm}$ size. The quantities for each cube were mixed and compacted in three layers with 25 blows each. Nine samples were prepared for each mix. The cubes were cured in a separate water tank and later it was tested with the compression testing machine at the rate of loading as $1.5 \mathrm{KN} / \mathrm{sec}$ after 3 days, 7 days and 28 days.

\subsection{Concrete}

Concrete specimens were prepared to study the mechanical properties of concrete such as compressive strength and split tensile strength. To the mix design arrived, the quantities per $\mathrm{m}^{3}$ of concrete were cement $=425.73 \mathrm{~kg} / \mathrm{m}^{3}$, water $=$ $191.58 \mathrm{~kg} / \mathrm{m}^{3}$, fine aggregate $=637.07 \mathrm{~kg} / \mathrm{m}^{3}$, coarse aggregate $=1161.4 \mathrm{~kg} / \mathrm{m}^{3}$. Concrete cubes and cylinders were casted for five water samples. Adopted water cement ratio was 0.45 . Nine specimens were casted to conduct the compressive strength for 3 days, 7 days, and 28 days. Further, concrete cylinders were prepared for the split tensile strength. Nine specimens were casted for testing of 3 days, 7 days and 28 days. In total 45 cubes and 45 cylinders were casted. Specimens were cured in potable water until the age of curing. The compressive strength and split tensile strength were done corresponding days in compression testing machine with 2 $\mathrm{kN} / \mathrm{sec}$ as rate of loading. 
Table-4: Chemical characteristics of water samples

\begin{tabular}{|c|c|c|c|c|c|c|}
\hline \multirow{2}{*}{ Parameter } & \multicolumn{4}{|c|}{ Concentration } & \multirow{2}{*}{$\begin{array}{l}\text { Tolerable } \\
\text { limits }\end{array}$} & \multirow{2}{*}{ Reference } \\
\hline & CTW & AOW & TCW & ROFW & & \\
\hline $\mathrm{pH}$ at $30 \operatorname{deg} \mathrm{C}$ & 9.34 & 7.5 & 11.81 & 6.82 & $6.0-8.0$ & McCoy (1978) \\
\hline Total solids, ppm & 5520 & 10816 & 11992 & 6560 & 50,000 & ASTM C1602 \\
\hline Sulphates as $\left(\mathrm{SO}_{4}\right), \mathrm{ppm}$ & 310 & 1070 & 1250 & 178 & 3000 & ASTM C1602 \\
\hline Chlorides as cl, ppm & 2000 & 4900 & 5450 & 3350 & 1000 & ASTM C1602 \\
\hline Total Alkalinity & 550 & 330 & 260 & 200 & 600 & ASTM C1602 \\
\hline Sodium, ppm & 1988 & 4017 & 4594 & 2713 & 2000 & BSI \\
\hline Calcium,ppm & 200 & 230 & 530 & 220 & 2000 & BSI \\
\hline Nitrates as $\mathrm{No}_{3}^{-}, \mathrm{mg} / \mathrm{l}$ & 17 & 3.5 & 12.7 & 16.5 & 500 & BSI \\
\hline Manganese (Mn),mg/l & 0.15 & 1.07 & 0.13 & 0.09 & 500 & Mindness(1981) \\
\hline
\end{tabular}

\section{TEST RESULTS AND DISCUSSION}

\subsection{Cement Pastes}

Table 5 shows the consistency, initial and final setting time of cement. A minimum setting time of 1 hour is prescribed by BS 1008:2002 and final setting time should not be greater than 12 h. The specifications that stipulate a limit in the change in initial setting time tolerance in accordance with IS 456:2000 is that, the water proposed to use shall not be less than $30 \mathrm{~min}$ and shall not differ by \pm 30 min from the initial setting time of control test blocked prepared. With the results presented below the CTW sample does not fall under the limit, due to higher $\mathrm{pH}$ in CTW it was observed to aid precipitation of metals which in turn minimizes retardation effect on cement hydration [5]

Table-5: Setting time of cement made with Textile Effluent water

\begin{tabular}{|l|l|l|l|}
\hline $\begin{array}{l}\text { Type of } \\
\text { Water }\end{array}$ & Consistency \% & $\begin{array}{l}\text { Initial setting } \\
\text { time }\end{array}$ & $\begin{array}{l}\text { Final setting } \\
\text { time }\end{array}$ \\
\hline PW & 31 & $80 \mathrm{mins}$ & $105 \mathrm{mins}$ \\
\hline CTW & 31 & $35 \mathrm{mins}$ & $150 \mathrm{mins}$ \\
\hline AOW & 29 & $60 \mathrm{mins}$ & $240 \mathrm{mins}$ \\
\hline TCW & 30 & $95 \mathrm{mins}$ & $270 \mathrm{mins}$ \\
\hline ROFW & 29 & $70 \mathrm{mins}$ & $180 \mathrm{mins}$ \\
\hline
\end{tabular}

\subsection{Workability}

The workability of concrete should be measured at frequent intervals during the progress of work, by means of slump test. The slump tests were carried out for water samples taken and the results are tabulated in Table 4.2. The slump assumed was between $50-100 \mathrm{~mm}$ where the degree of workability is adopted as medium for construction of beams, walls, columns (IS 456:2000). The slump value obtained was between 50-100.
However the value of AOW exceeds the designed slump. It was referred that the sump should be affected by water content and not water quality [17]

Table-6: Slump of concrete made with Textile Effluent water

\begin{tabular}{|l|l|}
\hline Water type & Slump $(\mathrm{mm})$ \\
\hline PW & 72 \\
\hline CTW & 75 \\
\hline AOW & 130 \\
\hline TCW & 50 \\
\hline ROFW & 60 \\
\hline
\end{tabular}

\subsection{Cement Mortar Cubes}

Table 7 presents the compressive strength of cement mortars prepared using fine aggregate, water and cement. The results obtained using various water samples are comparable equal with the results obtained with the potable water. The compressive strength attained by mixing AOW shows higher early strength and later strength when compared with other water samples.

Table-7: Compressive strength for mortar cubes

\begin{tabular}{|l|l|l|l|}
\hline $\begin{array}{l}\text { Water } \\
\text { type }\end{array}$ & $\begin{array}{l}3 \text { days } \\
\text { strength } \\
\mathrm{N} / \mathrm{mm}^{2}\end{array}$ & $\begin{array}{l}7 \text { days } \\
\text { strength } \\
\mathrm{N} / \mathrm{mm}^{2}\end{array}$ & $\begin{array}{l}28 \text { days } \\
\text { strength } \\
\mathrm{N} / \mathrm{mm}^{2}\end{array}$ \\
\hline PW & 22.102 & 31.395 & 48.37 \\
\hline CTW & 20.546 & 30.546 & 50.83 \\
\hline AOW & 33.27 & 34.413 & 53.413 \\
\hline TCW & 22.304 & 35.026 & 51.026 \\
\hline ROFW & 24.413 & 33.70 & 46.58 \\
\hline
\end{tabular}




\subsection{Concrete}

\subsubsection{Compressive Strength}

Compressive strength obtained for 3 days, 7 days and 28 days were furnished in Table 8. Chart 1 depicts the results obtained. Compressive strength increased with longer curing periods for all water samples. The higher early strength associated with AOW concrete could be the result of the chemical and physical properties of this particular effluent. The principal properties that could be of advantage in this case include presence of chloride ions and higher amount of solids at this stage [1]

Table-8: Compressive strength of concrete made with Textile Effluent water

\begin{tabular}{|l|l|l|l|}
\hline $\begin{array}{l}\text { Water } \\
\text { type }\end{array}$ & $\begin{array}{l}3 \text { days } \\
\text { strength } \\
\mathrm{N} / \mathrm{mm}^{2}\end{array}$ & $\begin{array}{l}7 \text { days } \\
\text { strength } \\
\mathrm{N} / \mathrm{mm}^{2}\end{array}$ & $\begin{array}{l}28 \quad \text { days } \\
\text { strength } \\
\mathrm{N} / \mathrm{mm}^{2}\end{array}$ \\
\hline PW & 23.364 & 28.373 & 39.83 \\
\hline CTW & 27.509 & 38.222 & 49.303 \\
\hline AOW & 32.58 & 37.392 & 54.2 \\
\hline TCW & 23.910 & 26.385 & 38.502 \\
\hline ROFW & 23.08 & 27.776 & 44.80 \\
\hline
\end{tabular}

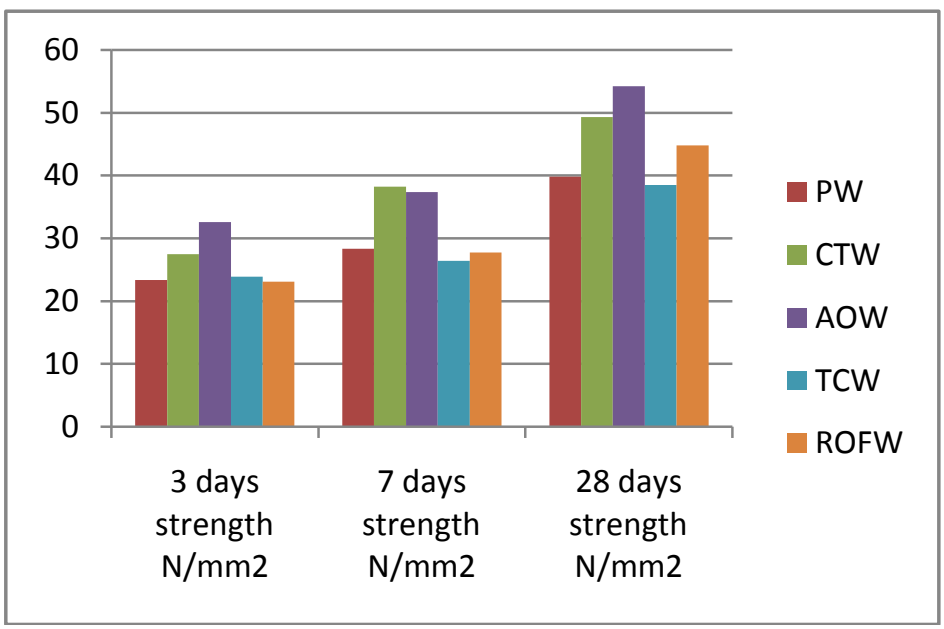

Chart-1: Compressive strength of concrete cubes for $3,7 \& 28$ days

\subsubsection{Split Tensile Strength}

Table 8 represents the split tensile strength of concrete made with various stages of textile effluent water samples. The split tensile strength obtained is compared with results obtained with specimen prepared using potable water. The early strength was attained by the specimens casted using TCW.
The later strength was attained by potable water when compared with the water samples casted

Table-8: Split tensile strength of concrete made with Textile Effluent water

\begin{tabular}{|l|l|l|l|}
\hline $\begin{array}{l}\text { Water } \\
\text { type }\end{array}$ & $\begin{array}{l}3 \text { day strength } \\
\left(\mathrm{N} / \mathrm{mm}^{2}\right)\end{array}$ & $\begin{array}{l}7 \text { day strength } \\
\left(\mathrm{N} / \mathrm{mm}^{2}\right)\end{array}$ & $\begin{array}{l}28 \text { day } \\
\text { strength } \\
\left(\mathrm{N} / \mathrm{mm}^{2}\right)\end{array}$ \\
\hline PW & 1.877 & 3.014 & 3.727 \\
\hline CTW & 1.844 & 2.330 & 2.33 \\
\hline AOW & 2.037 & 3.500 & 3.359 \\
\hline TCW & 2.103 & 2.212 & 2.986 \\
\hline ROFW & 2.028 & 2.608 & 2.637 \\
\hline
\end{tabular}

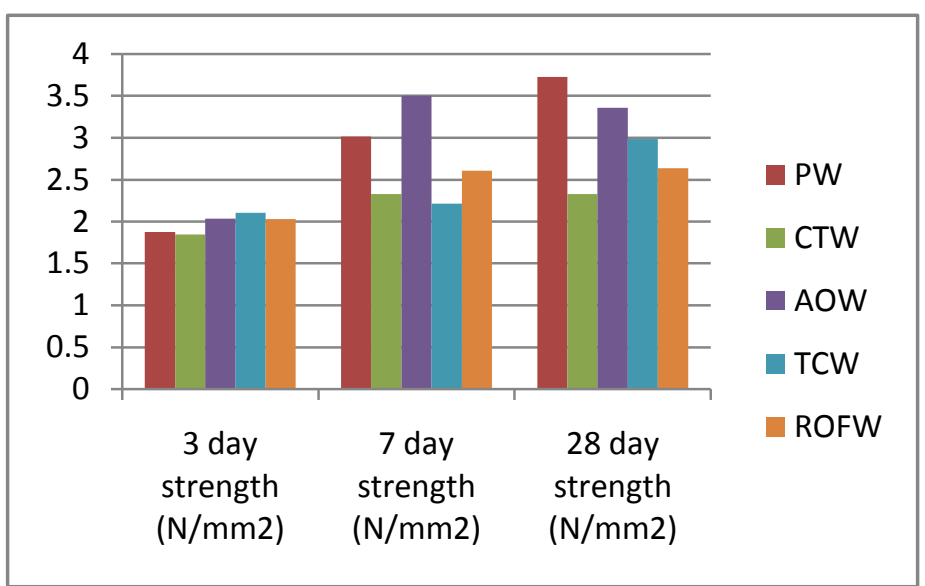

Chart-4: Split tensile strength of concrete cylinders for 3,7 \& 28 days

\section{CONCLUSIONS}

This study portrays that the concrete specimens could be successfully prepared using textile dyeing effluent. The chemical properties except sodium and chlorides all other properties were within the standard limit. However, it is advantageous in the strength properties in concrete.

- The setting time and compressive strength of mortar were moderate and tolerable.

- The compressive strength of cement mortar made with AOW was higher when compared with results obtained for potable water.

- In split tensile strength for concrete specimens the higher early strength was attained with TCW when compared with other water samples.

- It is quite feasible to utilize the AOW effluent to make concrete without the fear of jeopardizing the strength.

- Further study is needed on the durability properties on various water samples. 


\section{REFERENCES}

[1] Ainul Haezah Noruzman , Bala Muhammad, Mohammad Ismail , Zaiton Abdul-Majid (2012) 'Characteristics of treated effluents and their potential applications for producing concrete', Journal of Environmental Management, Elsevier, vol.110, pp. 2732.

[2] Aitcin, P.C., 2000. Cements of yesterday and today: concrete of tomorrow. Cement and Concrete Research 30 (9), 1349-1359

[3] Al-Harthy, A.S., Taha, R., Abu-Ashour, J., Al-Jabri, K., Al-Oraimi, S., 2005. Effect of water quality on strength of flowable fill mixtures. Cement and Concrete Composites 27 (1), 33-39.

[4] ASTM C 1602/C 1602M-06, 2006 Standard specification for mixing water used in the production of hydraulic cement concrete.

[5] Boardman, D.I., 1999. Lime Stabilization: ClayeMetaleLime-Interactions, $\mathrm{PhD}$ thesis. Loughborough University, United Kingdom.

[6] BS 3148, Method of tests for water for making concrete, London 1980.

[7] BS EN, 1008, 2002. Mixing Water for Concrete. Specification for Sampling, Testing and Assessing the Suitability of Water, Including Water Recovered from

[8] Cebeci O.Z , Saatci (1989) 'Domestic sewage as mixing water in concrete' ACI materials journals, 86(5):503-506

[9] Ibrahim Al, Ghusain and Mohammad J. Terro (2003) 'Use of treated waste water for concrete mixing in Kuwait' Kuwait Journal.science.Engineering vol.30 (1)

[10] Illston, J.M., Dinwoodie, J.M., Smith, A.A., 1979. Concrete Timber and Metals -The Nature and Behaviour of Structural Materials. Reinhold Company, Van Nostrand, Berkshire, England

[11] IS: 4031(part 4,5)-1998 Determination of consistency and setting time for cement paste.

[12] IS : 516 - 1959 methods of tests for Strength of concrete

[13] IS: 4031(part 6)-1998 Determination of compressive strength for cement mortar cubes.

[14] Kosmatka, S., Kerkhoff, B., Panarese, W., 2002. Design and Control Concrete of Concrete Mixtures. Portland cements Association, Illinois, USA.

[15] Lee, O.S., Salim, M.R., Ismail, M., Ali, M.I., 2001. Reusing treated effluent in concrete technology. Jurnal Teknologi 34(F), 1-10.

[16] Mindness, S., Young, J.F., 1981. Concrete. PrenticeHall, New Jersey.

[17] Nevillie, A.M.1981. Properties of concrete, Third edition, Longman scientific.

[18] Ooi soon lee, Mohd Razman Salim, Mohammad Ismail \&Md. Imtiaj ali (2001) 'Reusing treated effluent in concrete Technology' Journal Teknologi, 34(F) Jun, pp. $1-10$
[19] R.Rajamanickam and S.Nagan (2010) 'Groundwater Quality Modeling of Amaravathi River Basin of Karur District, Tamil Nadu, Using Visual Modflow', International journal of environmental sciences Vol. 1, No.1.

[20] Tony, C.L., Jenn, C.C., 2008. Sustainable concrete technology for the 21st century. In: Proceedings of the 3rd ACF International Conference-ACF/VCA. pp. 168174.

\section{BIOGRAPHIES}

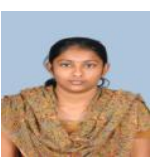

${ }^{1}$ Pursuing Masters in Construction Engineering and Management in Erode Builder Educational Trusts, Kangayam.

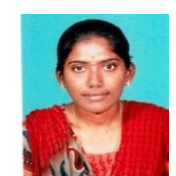

${ }^{4}$ Pursuing Masters in Construction Engineering and Management in Erode Builder Educational Trusts, Kangayam. 